University of Nebraska - Lincoln

DigitalCommons@University of Nebraska - Lincoln

USDA Forest Service / UNL Faculty Publications U.S. Department of Agriculture: Forest Service -National Agroforestry Center

2007

Characterizing Stand- Replacing Harvest and Fire Disturbance

Patches in a Forested Landscape: A Case Study from Cooney

Ridge, Montana

\author{
Andrew T. Hudak \\ Rocky Mountain Research Station, ahudak@fs.fed.us \\ Penelope Morgan \\ University of Idaho, pmorgan@uidaho.edu \\ Michael J. Bobbitt \\ University of Idaho, mbobbitt@uidaho.edu \\ Leigh B. Lentile \\ University of Idaho, lentile@uidaho.edu
}

Follow this and additional works at: https://digitalcommons.unl.edu/usdafsfacpub

Hudak, Andrew T.; Morgan, Penelope; Bobbitt, Michael J.; and Lentile, Leigh B., "Characterizing StandReplacing Harvest and Fire Disturbance Patches in a Forested Landscape: A Case Study from Cooney Ridge, Montana" (2007). USDA Forest Service / UNL Faculty Publications. 219.

https://digitalcommons.unl.edu/usdafsfacpub/219

This Article is brought to you for free and open access by the U.S. Department of Agriculture: Forest Service -National Agroforestry Center at DigitalCommons@University of Nebraska - Lincoln. It has been accepted for inclusion in USDA Forest Service / UNL Faculty Publications by an authorized administrator of DigitalCommons@University of Nebraska - Lincoln. 


\title{
8 Characterizing Stand- Replacing Harvest and Fire Disturbance Patches in a Forested Landscape: A Case Study from Cooney Ridge, Montana
}

\author{
Andrew T. Hudak, Penelope Morgan, \\ Mike Bobbitt, and Leigh Lentile
}

\section{CONTENTS}

Introduction

Forest Harvest and Fire Disturbances

Objective and Analysis Approach

Methods

Study Area

Geographic Information Layers

Image Preprocessing

Image Analyses

Patch Analyses

Results

Extent of Forest Harvest and Fire Disturbances........................................216

Patch Characteristics of Stand-Replacing Disturbances ............................217

Contrasts between Stand-Replacing Harvest and Fire Disturbance

Patches......

Discussion

Remote Sensing of Forest Pattern and Disturbance Processes

Patch Characteristics of Stand-Replacing Harvest and Fire

Disturbance.

Interaction of Forest Harvest and Fire Disturbance Processes 


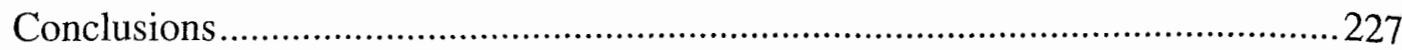

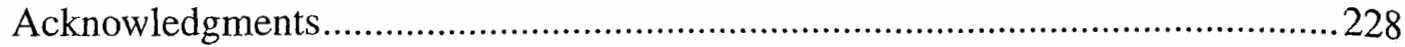

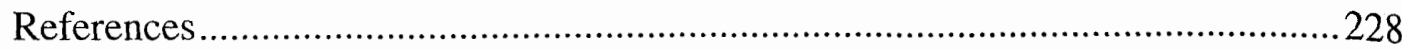

\section{INTRODUCTION}

In this chapter, we present a case study intended to help crystallize for many readers, through use of an illustrative example, some of the important concepts developed in the preceding chapters. From an understanding of forest successional and disturbance processes, both natural and anthropogenic (Linke et al., Chapter 1 , this volume), research questions were developed to compare and contrast the landscape patterns generated from fire and harvest disturbance. Remotely sensed data are demonstrated as an appropriate source of relevant information (Coops et al., Chapter 2, this volume), enabling the applications presented for the utilization of change detection approaches for mapping of forest harvest (Healey et al., Chapter 3 , this volume) and fire (Clark and Bobbe, Chapter 5, this volume). As presented in Chapter 6 (Rogan and Miller, this volume), the use of supportive spatial data sets to aid in the analysis and interpretation of the maps and patterns exhibited is demonstrated. The forest harvest and fire maps are subjected to pattern analysis as outlined by Gergel (Chapter 7, this volume), providing insights into the research questions identified.

\section{Forest Harvest and Fire Disturbances}

Timber harvest and fire are influential disturbance processes affecting many forested landscapes in the American West. These forests are managed for a variety of human values, including residential, recreational, wildlife habitat, water quality, and wood production purposes. If managers are to mimic the effects of natural disturbances, then they must integrate the timing and severity of prescribed disturbances with the ecological requirements of the desired landscape composition and condition. Understanding the effects of different types of disturbances and associated alteration of key processes may help to promote ecosystem resiliency through improved management decisions (Kimmins, 1997). Both forest and fire management practices influence succession, and the individual and cumulative effects of disturbances may have positive and negative implications for ecosystem character and function (Moore et al., 1999; Tinker and Baker, 2000). Development of sustainable relationships between humans and their environments requires knowledge of successional consequences.

Forest harvests vary in extent and intensity, but some degree of change in soil and water properties and loss of nutrients will occur in any harvested system (Pritchett and Fisher, 1987). In general, clearcutting alters microclimatic, soil, vegetation, animal habitat, and microbial conditions more severely than less-intensive or partial cutting. Clearcutting favors early successional microclimates and tolerable levels of vegetation competition but may not create the type of forest floor environment conducive to regeneration of desired species (Kimmins, 1997). High surface temperatures and low surface soil moisture content may lead to slow revegetation rates 
following clearcutting, although invasive species may find these conditions favorable (Pritchett and Fisher, 1987). Forest harvest, especially clearcutting, may have greater influence in hot and dry climates or on steep slopes where the potential for soil erosion and slow rates of plant recovery is high, particularly if timber harvesting is coupled with other intensive practices such as grazing, repeat burning, and farming (Smith et al., 1996). Furthermore, clearcutting results in fragmented forests with altered age, structural, and spatial characteristics, which may have important implications for wildlife habitat, bird nesting success, and landscape diversity (Mladenoff et al., 1993; Tinker and Baker, 2000).

The term burn severity is broadly defined as the degree of ecosystem change induced by fire and encompasses fire effects on both vegetation and surface soils (Key and Benson, in press; Ryan, 2002; Ryan and Noste, 1985). Severe fires are those that result in great ecological changes (De Bano et al., 1998; Johnson et al., 2003; Moreno and Oeschel, 1989; Rowe, 1983; Ryan, 2002; Ryan and Noste, 1985; Schimmel and Granstrom, 1996). If "severity" is considered a relative term, then severe fires are so named because they slow vegetation recovery, alter nutrient cycles, or increase abundance of invasive species, tree mortality, or soil erosion potential to an undesirable, perhaps even unnatural, degree. The short-term effects of recent severe fires have been studied (Graham, 2003; Lewis et al., 2006; Turner et al., 1997), but there remains limited understanding of the longer-term effects of severe fires on forest demography and structure (Savage and Nystrom Mast, 2005).

Burn severity varies greatly at fine scales in Africa (Brockett et al., 2001), North America (Hudak, Morgan, et al., 2004; Hudak, Robichaud, et al., 2004), and elsewhere, but the causes and consequences of that spatial variability in terms of postfire effects are poorly understood. Recent developments in remote sensing and vegetation pattern analysis allow the evaluation of burn severity, which influences subsequent vegetation recovery (White et al., 1996). The degree to which prior timber harvest and other vegetation conditions have influenced fire effects across landscapes is little understood yet has tremendous implications for the efficacy of fuel management designed to moderate fire effects.

\section{Objective and Analysis Approach}

Our objective is to demonstrate consistent and objective use of remote sensing and geographical information system (GIS) tools to characterize and compare the patch characteristics of stand-replacing harvest and fire disturbance processes in a coniferous forest landscape where both disturbances were known to have recently occurred. Consistency and objectivity are required for conducting a reliable remote sensing analysis in the absence of explicit ground validation data (Hudak and Brockett, 2004; Hudak, Fairbanks, et al., 2004), as was the case in this study. We do, however, have substantial and sufficient local knowledge of the Cooney Ridge area and wildfire event to conduct this study.

The two satellite-based spectral indices applied in this analysis were the middleinfrared corrected normalized difference vegetation index (NDVIc) (Nemani et al., 1993 ) and the normalized burn ratio (NBR) (Key and Benson, in press). Pocewicz et al. (2004), working in mixed-conifer forest in the northern Rocky Mountains, 
found NDVIc to be a better predictor of leaf area index than the more broadly applied, uncorrected NDVI; "correcting" the NDVI with a middle-infrared band increased the sensitivity of the index to forest biomass. Therefore, we selected NDVIc to indicate forest biomass.

Key and Benson (in press) found that NBR outperformed NDVI as a predictor of composite burn index, an integrated, ecological field measure of burn severity based on vegetation and soil effects, due to the higher sensitivity of NBR to soil effects. As a result, NBR is the burn severity index used by the U.S. Forest Service Remote Sensing Applications Center (RSAC) and the U.S. Geological Survey Earth Resources Observation and Science Data Center; both produce burned area reflectance classification (BARC) maps to inform rapid response Burned Area Emergency Rehabilitation (BAER) team decisions on large, active wildfire events (as described in Clark and Bobbe, Chapter 5, this volume). We also selected NBR to indicate burn severity in this study, but it must be noted that both NDVI and NBR are more sensitive to green vegetation cover than to the underlying soils (Hudak, Morgan, et al., 2004; Hudak, Robichaud, et al., 2004). Therefore, in this study we consider "severe fire" to be more indicative of a lack of green vegetation cover than to any soil effects.

Because we wished to map forest cover change as a result of stand-replacing harvest and fire disturbances rather than simply forest cover condition, whenever possible we employed image-differencing techniques (delta, d) to indicate forest harvest with dNDVIc and fire-induced vegetation mortality with dNBR.

\section{METHODS}

\section{Study Area}

The study area $(20,672 \mathrm{Ha})$ is topographically rugged, with elevations ranging from 1129 to $2353 \mathrm{~m}$ (Figure 8.1 and Figure 8.2). Vegetation is mixed-conifer forest type, with the important conifer species Pseudotsuga menziesii (Douglas fir), Larix occidentalis (western larch), Pinus contorta (lodgepole pine), Pinus ponderosa (ponderosa pine), Abies lasiocarpa (subalpine fir), and Picea engelmannii (Engelmann spruce) (A. Hudak, 2003). Common shrubs are Physocarpus malvaceus (mallow ninebark), Alnus incana (thinleaf alder), Symphoricarpos albus (common snowberry), Rubus parviflorus (thimbleberry), Shepherdia canadensis (russet buffaloberry), Vaccinium membranaceum (thinleaf huckleberry), Spiraea betulifolia (birchleaf spirea), Mahonia repens (creeping barberry), Acer glabrum var. douglasii (Rocky Mountain maple), Lonicera utahensis (Utah honeysuckle), and Rosa spp. (rose). Common forbs include Chamerion angustifolium (fireweed), Arnica cordi folia (heartleaf arnica), Apocynum androsaemifolium (spreading dogbane), Linnaea borealis (twinflower), and Xerophyllum tenax (common beargrass). Common grasses include Calamagrostis rubescens (pinegrass), Festuca idahoensis (Idaho fescue), Phleum pratense (timothy), Agrostis scabra (ticklegrass), and Elymus glaucus (blue wildrye) (L. Lentile, 2004). Equisetum spp. (horsetail) and Peltigera aphthosa (freckle pelt lichen) commonly occur. Centaurea maculosa (spotted knapweed), a

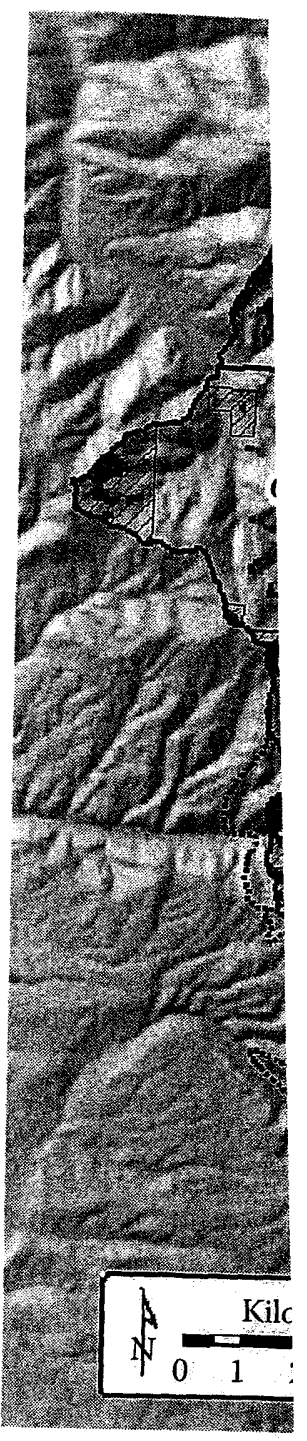

FIGURE 8.1 Shade Path/Row footprints. ranked in ascending c Lands within the stu

Category I noxious Forest habitat type types that support contorta is a persi subalpine habitat $\mathrm{t}$ infrequent but seve

The Cooney Ric during the 2003 fire ning ignited the $\mathrm{w}$. 


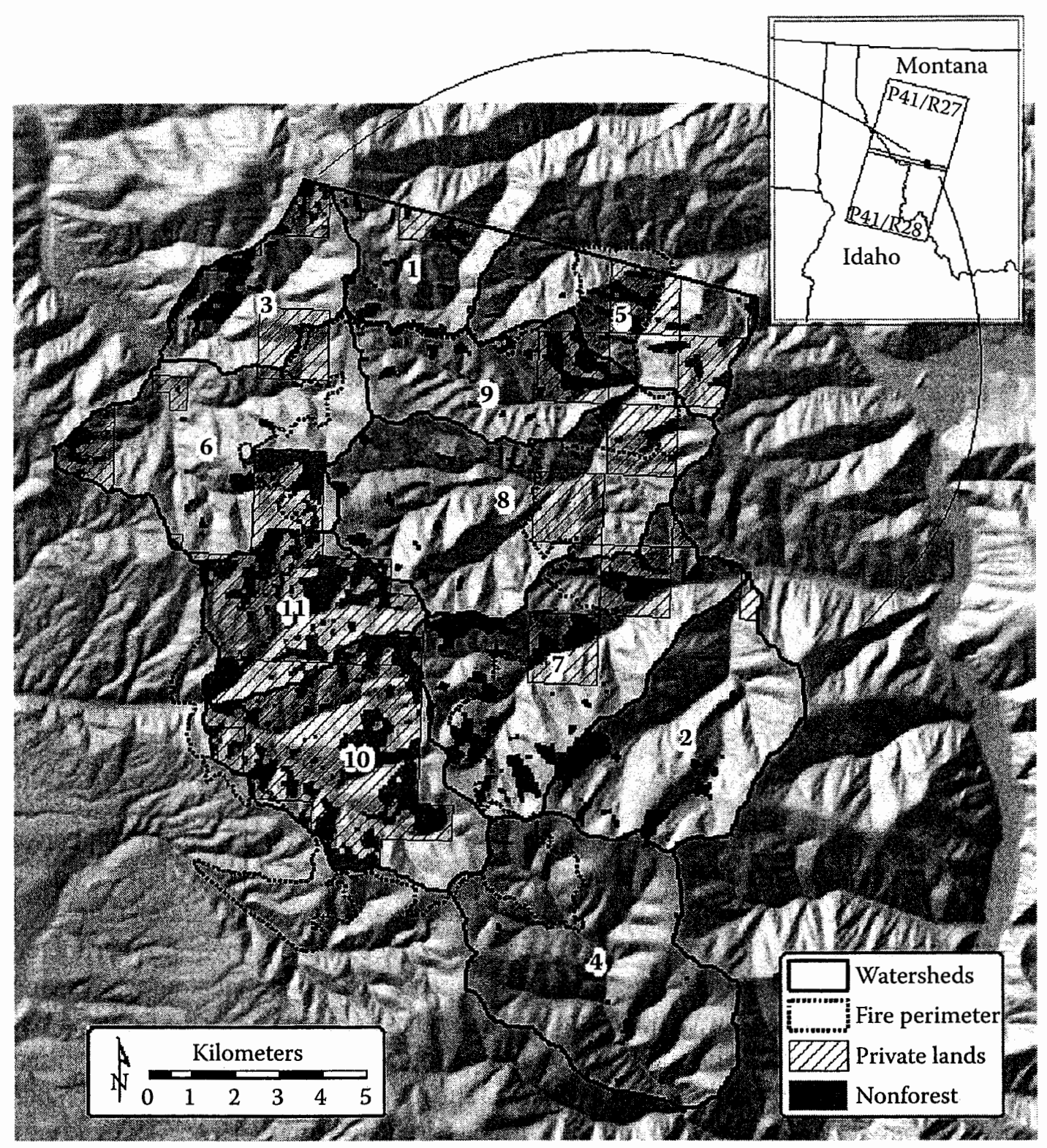

FIGURE 8.1 Shaded relief of the Cooney Ridge study area in relation to the relevant Landsat Path/Row footprints. The 11 watersheds defining the study area $(20,672 \mathrm{Ha})$ are delineated and ranked in ascending order according to proportion within the 26 August 2003 wildfire perimeter. Lands within the study area not indicated as private or nonforest are public forest lands.

Category I noxious weed in Montana, frequents roadsides and other disturbed areas. Forest habitat types in the study area range from warm, dry $P$. menziesii habitat types that support fire-maintained $P$. ponderosa, to cooler habitat types where $P$. contorta is a persistent dominant sometimes maintained by fire, to moist lower subalpine habitat types with $A$. lasiocarpa and $P$. engelmannii, where fires are infrequent but severe with long-lasting effects (Fischer and Bradley, 1987).

The Cooney Ridge wildfire was one of several large wildfire events that occurred during the 2003 fire season in western Montana (Figure 8.1 and Figure 8.2). Lightning ignited the wildfire at several locations on 8 August 2003 (Cooney Ridge 


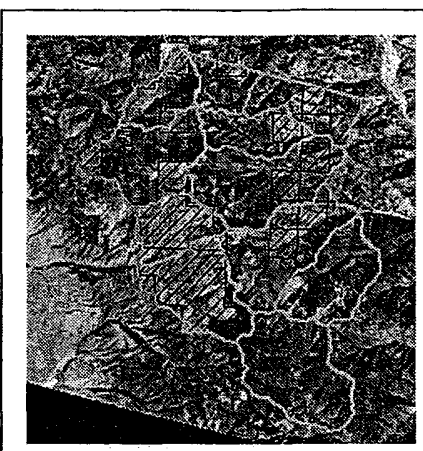

(a)

Watersheds एIIA Private lands

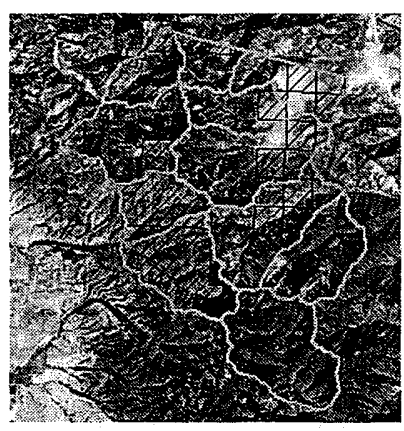

(b)

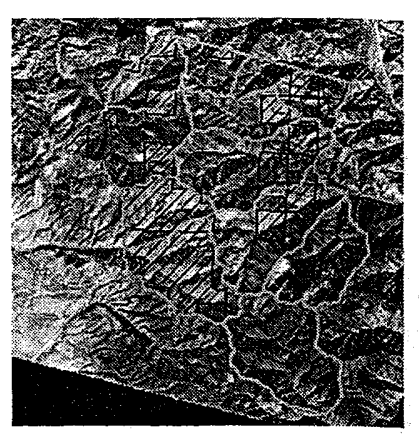

(c)

TABLE Lands; Chara! Imą

31 July

9 Septen 10 July ? 31 Augu: 25 Septe

forest GIS lay study area wa

FIGURE 8.2 (See color insert following page 146.) Color infrared composite images of the Cooney Ridge study area (a) 1 year before the wildfire (10 July 2002); (b) during the wildfire (31 August 2003) Note the smoke obscuring the image in the northeastern corner of the burned area; and (c) 1 year after the wildfire (25 September 2004).

Complex Fire Narrative, 2003), and despite intensive suppression efforts, it burned $9600 \mathrm{Ha}$ before it was finally contained on 15 October 2003.

\section{Geographic Information LAYers}

As noted in Chapter 6, information stored in a GIS can be used to aid forest change analyses by constraining or focusing the change detection efforts, with the goal of extracting more complete and accurate information from spectral data. Four GIS layers proved vital in this case study: watersheds, land ownership, wildfire perimeter, and a forest/nonforest classification. The watershed layer was delineated by applying the TerraFlow (http://www.cs.duke.edu/geo*/terraflow) model to a 30-m digital elevation model obtained from the U.S. Geological Survey National Elevation Dataset. An ownership layer from the state of Montana (http://nris.state.mt.us) indicated lands are $72 \%$ public national forest and $28 \%$ private industrial timberland. The Cooney Ridge wildfire perimeter originated from the Incident Command GIS team at the Incident Command camp where fire suppression operations were based and is dated 26 August 2003, when the wildfire perimeter had reached its maximum extent A forest/nonforest map was generated by an image analyst at RSAC based on the six reflectance bands from a 10 July 2002 Landsat ETM+ (Enhanced Thematic Mapper Plus) image (Table 8.1), using commercial See5 software for thematic classification (www.rulequest.com). The RSAC image analyst trained the classification with 50 forest and 50 nonforest sample points selected across a broader image subset (approximately three times the size) surrounding the study area; classification accu racy was estimated to be $99 \%$ (with 1 point misclassified). In this case, nonforest was defined as land cover not dominated by green vegetation canopy at the time of image acquisition and as such includes clearcuts, possibly other recent stand-replacing harvest treatments, or natural openings with little vegetation cover, such as rock outcroppings or meadows. The land ownership, burned/unburned, and forest/non-

\section{Image Preprc}

We acquired corrected usin Landsat Archi North). Imagil used to perfor

Calculatio] from multiple : Raw digital nı (NASA, 1989). to top-of-atmos and biases, sun al., Chapter 2,

The NDVI as follows,

NDVIc

where B3 = red TM (Thematic constants used imum and maxi correspond to $\mathrm{c}$

IMAGE ANALYSE

The calibrated : brated earlier $\mathrm{d} \varepsilon$ 


\begin{tabular}{|c|c|c|c|c|}
\hline Image date & Sensor & Path/row & Indices used & Condition indicated \\
\hline 31 July 1995 & TM & $41 / 28$ & NDVIc & Preharvest \\
\hline 9 September 2001 & ETM+ & $41 / 27$ & NBR, NDVIc & Prefire \\
\hline 10 July 2002 & ETM+ & $41 / 27$ & NDVIc & Postharvest \\
\hline 31 August 2003 & $\mathrm{TM}$ & 404112428 & NBR & Immediate postfire \\
\hline 25 September 2004 & $\mathrm{TM}$ & $41 / 27$ & NBR, NDVIc & One year postfire \\
\hline
\end{tabular}

rest GIS layers were intersected in ArcInfo, and the percentage of each within the udy area was calculated with an Excel pivot table.

\section{aAge Preprocessing}

le acquired five Landsat images (Table 8.1). All five images had been terrain orrected using digital elevation models to correct for relief displacement National andsat Archive Production (NLAPS) format and were projected to UTM (Zone 11 orth). Imagine (Leica Geosystems Geospatial Imaging, Norcross, Georgia,) was sed to perform all image processing functions.

Calculation of radiance is the fundamental step in standardizing raw image data om multiple sensors to a common radiometric scale (Chander and Markham, 2003). aw digital number values of spectral bands were converted to radiance values JASA, 1989). To reduce between-scene variability, spectral radiance was converted i top-of-atmosphere reflectance. This conversion accounted for variable sensor gains ad biases, sun angles, earth-sun distances, and solar spectral irradiances (Coops et ., Chapter 2, this volume).

The NDVIc and NBR spectral indices were calculated from the Landsat bands ; follows,

$$
\begin{gathered}
\mathrm{NDVIC}=(\mathrm{B} 4-\mathrm{B} 3) /(\mathrm{B} 4+\mathrm{B} 3) *\left[1-\left(\mathrm{B} 5-\mathrm{B} 5_{\min }\right) /\left(\mathrm{B} 5_{\max }-\mathrm{B} 5_{\min }\right)\right] \\
\mathrm{NBR}=(\mathrm{B} 4-\mathrm{B} 7) /(\mathrm{B} 4+\mathrm{B} 7)
\end{gathered}
$$

here $\mathrm{B} 3=$ red band, $\mathrm{B} 4=$ near-infrared band, and B5 and B7 are the two Landsat $\mathrm{M}$ (Thematic Mapper) and ETM+ middle-infrared bands. The $\mathrm{B} 5_{\min }$ and $\mathrm{B} 5_{\max }$ onstants used to "correct" NDVI (thus calculating NDVIc) are the full-scene minnum and maximum reflectance values in Band 5, respectively, and are assumed to orrespond to complete tree canopy closure and openness, respectively.

\section{nAGE ANALySES}

he calibrated later-date NDVIc and NBR images were subtracted from the calirated earlier dates to produce dNDVIc and dNBR (delta, d) images. A mask layer 
Stand-Re

was constructed from the 31 July 1995 TM scene edge and the boundaries for 11 watersheds of the same mixed-conifer forest type, which encompassed most of the wildfire perimeter (Figure 8.1). It was necessary to define the study area consistently in this manner, using density slices, to generate comparable mean and standard deviation statistics across all layers for the purpose of threshold-based classifications. Pixels exceeding two standard deviations from the mean clearly indicated the most pronounced land cover change (i.e., stand-replacing harvest or fire) based on visual inspection of the density slice results. All of the distributions were skewed in the direction of the disturbance, and a negligible few to none of the pixels on the opposite sides of the distributions exceeded two standard deviations from the mean, so the output layers were limited to two classes in all cases (i.e., standreplacing disturbance or not).

The edges of the two output classes after density slicing were heavily pixilated, so an edge-smoothing utility was applied to smooth the class boundaries while also eliminating single-pixel misclassifications. This caused the number of pixels belonging to the minority (disturbance) class to change by an average of $8 \%$. We did not consider this problematic because our intent was not to map the area disturbed accurately, but to define patches consistently and objectively where disturbance effects were most pronounced. The cleaned raster image classes were then converted into vector polygons on which patch metrics could be generated.

\section{Patch Analyses}

Many patch metrics are available, although they are often highly intercorrelated (Gustafson, 1998; Riitters et al., 1995). Based on our objective of characterizing landscape pattern effects due to stand-replacing harvest and fire disturbances, a review of quantifying landscape spatial pattern with patch metrics (Gustafson, 1998), and an analysis of landscape pattern change through time across forested landscapes in the region (Hessburg et al., 2000), we selected nine metrics that were thought to be readily interpretable and relevant (Table 8.2). Elkie et al. (1999) provide full details regarding ArcView Patch Analyst functions (ESRI, Redlands, CA).

The patch metrics were imported into $R$ (R Development Core Team, 2004) for Student $t$ tests to test for significant differences in the patch metrics between selected polygon layers of interest. Basing these tests on the entire polygon layers left too few degrees of freedom to produce reliable results. Therefore, more meaningful comparisons were made by partitioning the polygon layers by watershed and treating the watersheds as replicates, which greatly improved the available degrees of freedom to enable robust comparisons.

\section{RESULTS}

\section{Extent of Forest Harvest and Fire Disturbances}

We considered the nonforest areas in Figure 8.1 to be predominantly indicative of recent harvest disturbance (some areas such as rocky outcroppings or meadows do not support forest cover). Similarly, we considered the area within the wildfire

perimeter

Because tt: one could 8.3 sugges regarding watersheds (and signil expected $t$ regard to $c$ of private 1 cantly diff،

\section{Раtch $\mathrm{CH}_{\text {. }}$}

The image and one $\mathrm{dr}$ to 2002 anc most indica 8.5). The $\mathrm{p}$ size, edge, disturbance 


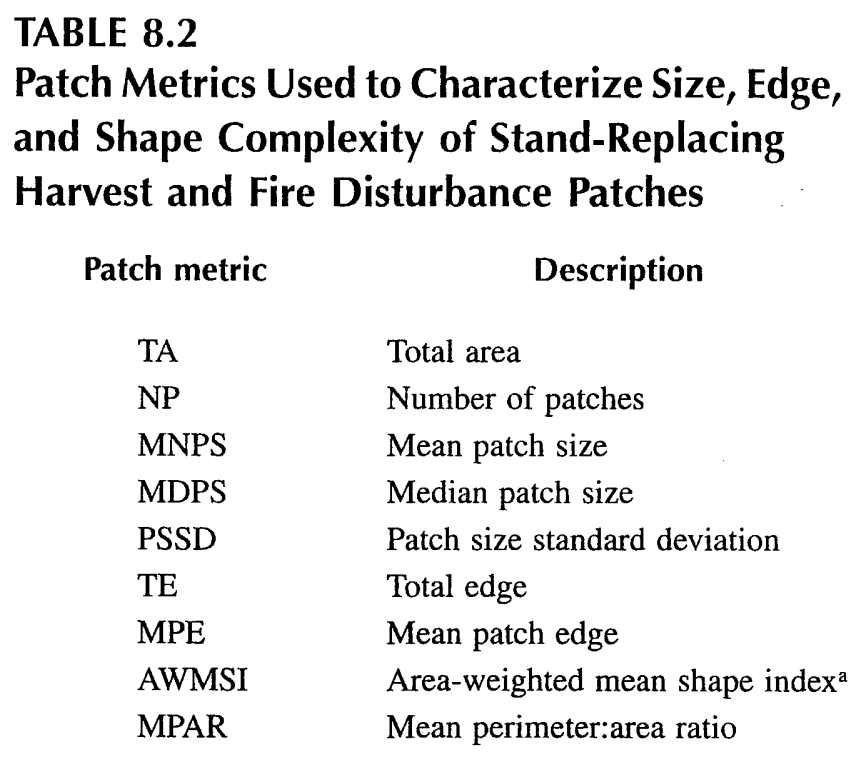

a AWMSI is a measure of shape complexity. AWMSI equals one when all patches are circular (polygons) or square (grids) and is greater than one when shapes are more complex; individual patch area weighting is applied to each patch. Because larger patches tend to be more complex than smaller patches, area-weighted measures have the effect of determining patch shape complexity independent of patch size (Elkie et al., 1999).

ter to have predominantly burned (although some areas did not burn). e these generalizations should apply equally to both private and public lands, ld assume that land ownership should have no effect on disturbance. Figure 'gests that private lands were relatively more disturbed than public lands ng both harvest and fire. Student $t$ tests conducted across the 11 paired leds indicated that indeed a significantly higher proportion of private lands gnificantly lower proportion of public lands) was nonforest than would be :d based on the observed nonforest proportion in each watershed without to ownership (Table 8.3). However, observed versus expected proportions ate (or public) lands that were inside the wildfire perimeter did not signifidiffer (Table 8.3).

\section{Characteristics of Stand-Replacing Disturbances}

age differencing and density slicing operations resulted in two NDVIc layers a dNDVIc layer considered most indicative of stand-replacing harvest prior ! and two NBR layers, two dNBR layers, and one dNDVIc layer considered dicative of stand-replacing fire from the 2003 wildfire (Figure 8.4 and Figure he patch metrics generated on these eight polygon layers quantified patch lge, and shape complexity (Table 8.4) of stand-replacing harvest and fire ances in this study area over the past decade. 


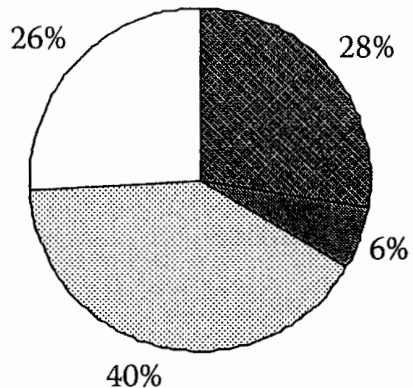

(a) Private Lands

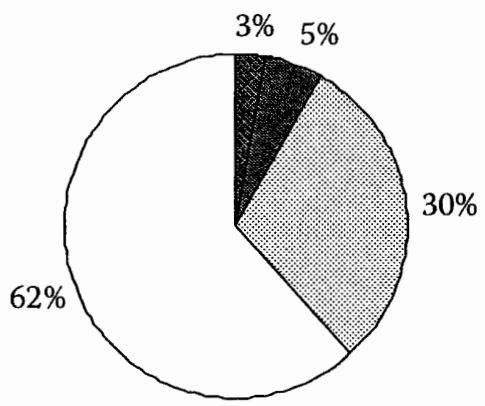

Nonforest, inside fire perimeter

Nonforest, outside fire perimeter

圈 Forest, inside fire perimeter

$\square$ Forest, outside fire perimeter

(b) Public Lands

FIGURE 8.3 Observed proportions of (a) private and (b) public lands that were nonforest or forest and inside or outside the wildfire perimeter.

TABLE 8.3

Student $t$-Test Results Comparing Observed versus Expected

Proportions of Private and Public Lands that Were Nonforest (and Likely Harvested) or Inside the Wildfire Perimeter (and Likely Burned)

\section{Land category}

Private lands

Observed versus expected, nonforest

Observed versus expected, inside fire perimeter

Public lands

Observed versus expected, nonforest

Observed versus expected, inside fire perimeter $|t|$ value $p$ value Significance $^{a}$

$\begin{array}{ccc}2.8761 & .0165 & * \\ 0.1509 & .8830 & \text { ns } \\ & & \\ 2.4039 & .0371 & * \\ 0.5481 & .5956 & \text { ns }\end{array}$

Note: The comparisons were paired across all 11 watersheds.

a $*=p<.05 ;$ ns $=$ not significantly different.

(1)

(3)

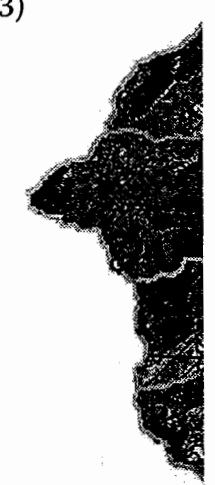

$1995-2002$

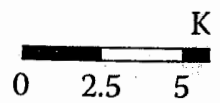

FIGURE 8.4A ( 31 July 1995 NL and (4) 9 Septer indicate patches polygons indicats as a result of th standard deviatio: than two standars 

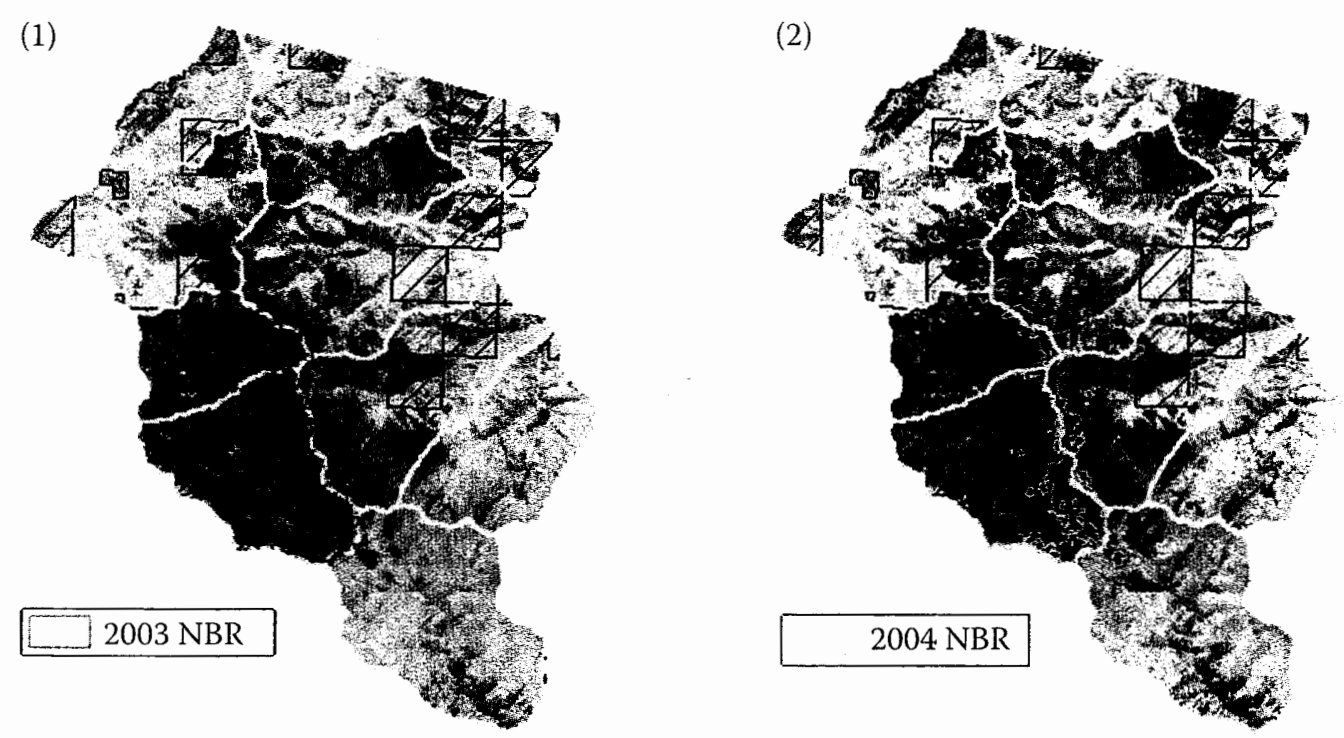

Integrating
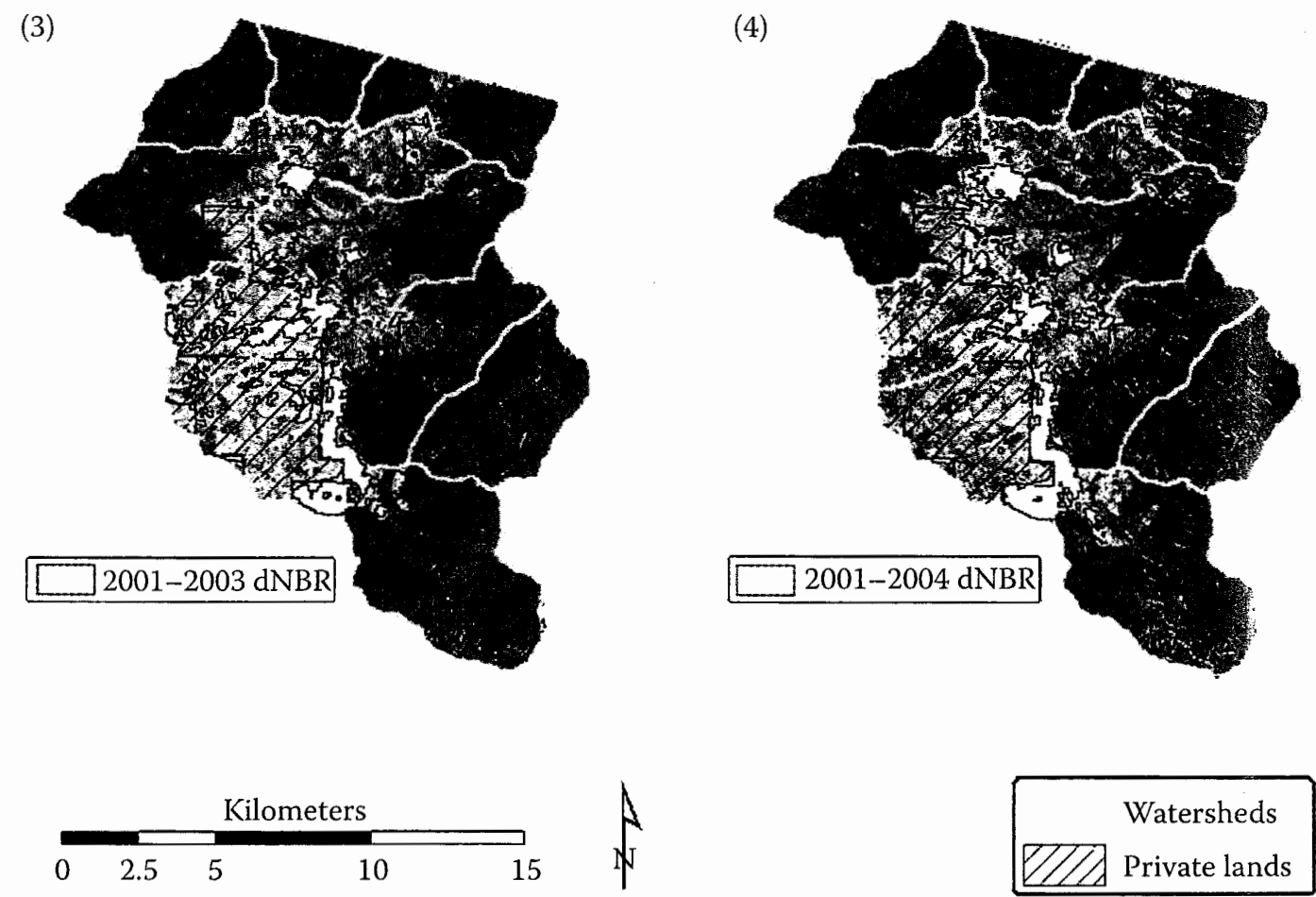

FIGURE 8.4B Stand-replacing disturbance maps: (1) 31 August 2003 NBR; (2) 25 September 2004 NBR; (3) 9 September 2001 to 31 August 2003 dNBR; and (4) 9 September 2001 to 25 September 2004 dNBR. The NBR-derived polygons indicate patches with minimal postfire green vegetation cover (Maps 1 and 2), and the dNBR-derived polygons indicate patches of severe fire-induced tree mortality due to the 2003 wildfire (Maps 3 and 4). The NBR-derived patches are more than two standard deviations below the mean image value, while the dNBRderived patches are more than two standard deviations above the mean image value. 


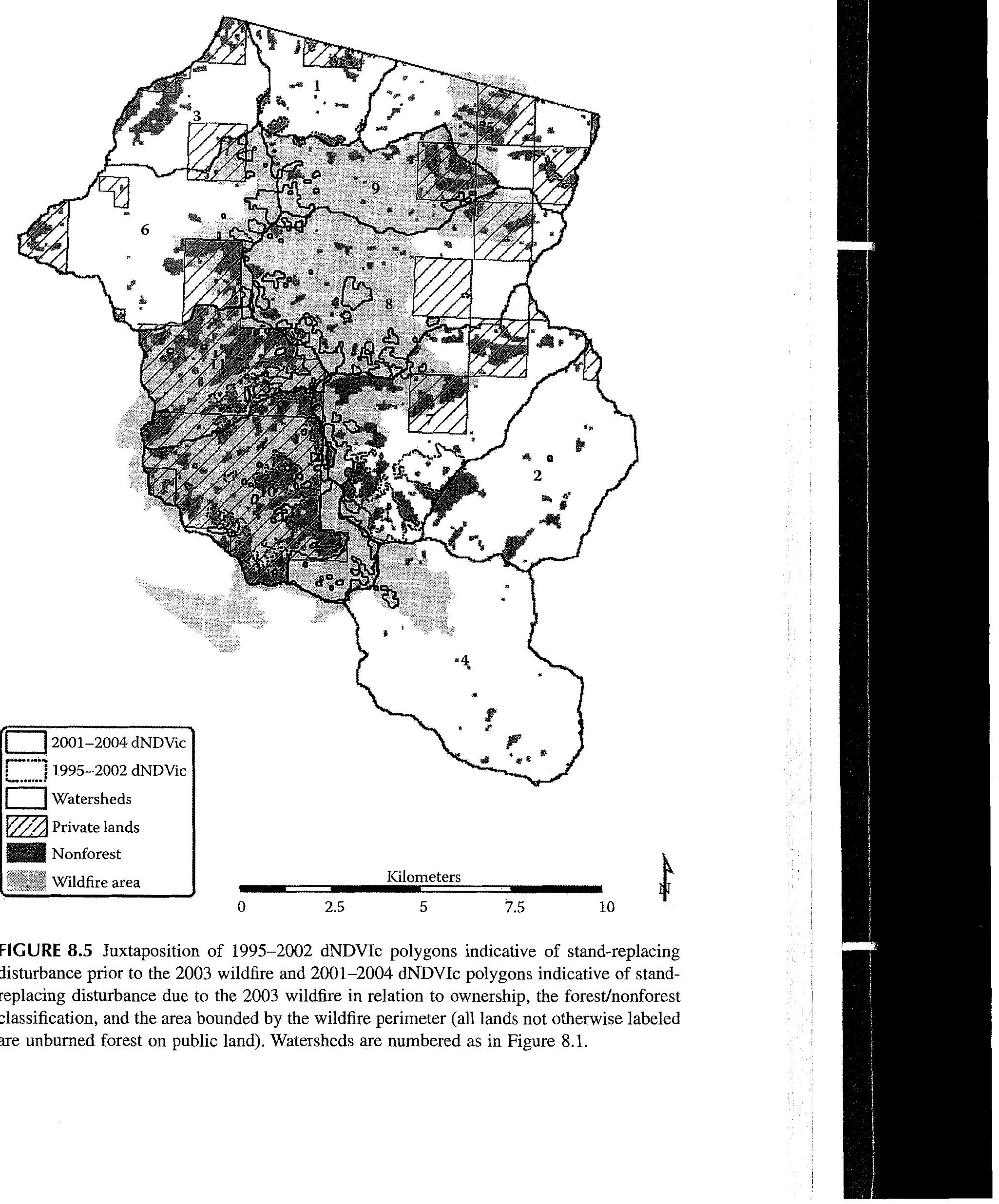


Stand-Repl

Contrasts

Disturban.

Comparing date images tions of sta could be cor from the tw The NBR $p$ patch size ar harvest (Tal Student watersheds) 2002 than ir in 2002 than (pairing the differences. in the NBR 1 from images year apart. $C$ dNDVIc layı no significan

$\frac{\sum^{2}}{2}$

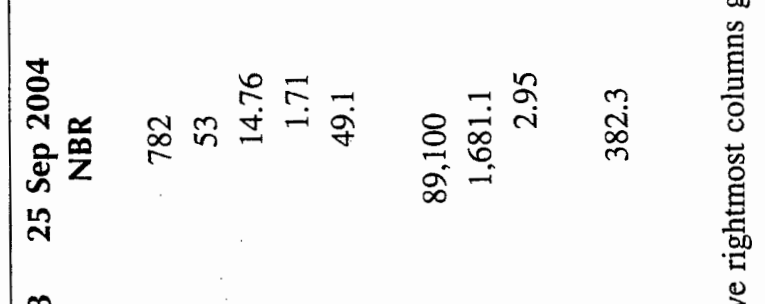

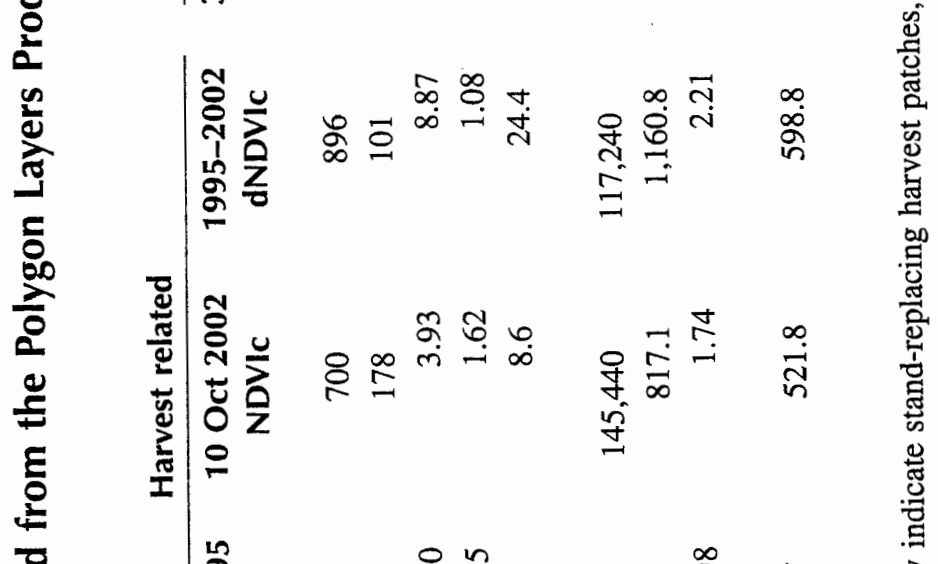

T.

St

fri

In

M

Se

Fil

อ

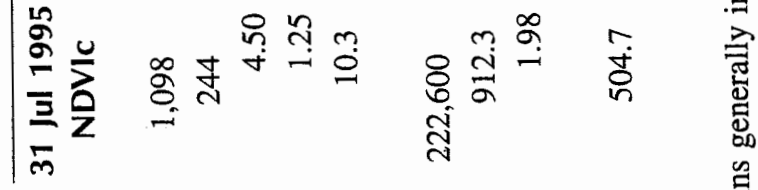

Tot

$\mathrm{Nu}$

$\mathrm{Me}$

$\mathrm{Me}$

ลิ

$\frac{0}{2}$

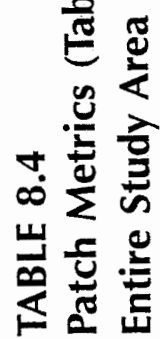

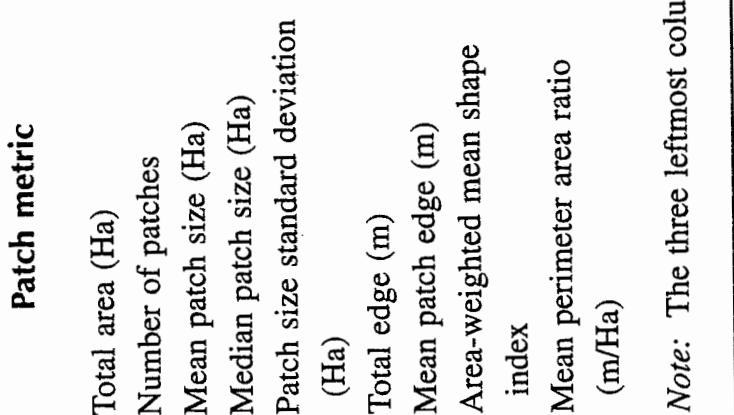

Tot:

Me:

Are

Mé

Not

four 


\section{Contrasts between Stand-Replacing Harvest and Fire Disturbance Patches}

Comparing the patch metrics from delta (difference) images to those from the singledate images (Table 8.1) used to derive the delta images would have violated assumptions of statistical independence, which limited the number of comparisons that could be conducted. The most robust Student $t$ tests compared patch metrics averaged from the two NDVIc layers to patch metrics averaged from the two NBR layers. The NBR patches indicative of stand-replacing fire had significantly higher mean patch size and mean patch edge than the NDVIc patches indicative of stand-replacing harvest (Table 8.5).

Student $t$ tests contrasting the two independent NDVIc layers (pairing all 11 watersheds) revealed fewer patches $(p=.0153)$ and less total edge $(p=.0445)$ in 2002 than in 1995. This may indicate fewer recent stand-replacing harvest patches in 2002 than in 1995. Comparisons of the independent 2003 and 2004 NBR layers (pairing the 7 watersheds with stand-replacing fire patches) showed no significant differences. Finding more significant differences in the NDVIc layer contrast than in the NBR layer contrast is to be expected given that the NDVIc layers were derived from images 7 years apart, while the NBR layers were derived from images only 1 year apart. Comparisons of the independent 1995-2002 dNDVIc and 2001-2004 INDVIc layers (pairing the 8 watersheds with patches in both layers) again found no significant differences.

\section{TABLE 8.5}

\section{Student t-Test Results Contrasting Patch Metrics Averaged from the 31 July 1995 and 10 July 2002 NDVIc Layers Indicating Stand-Replacing Harvest Patches with Patch Metrics Averaged from the 31 August 2003 and 25 September 2004 NBR Layers Indicating Stand-Replacing Fire Patches}

\section{Patch metric}

Total area

Number of patches

Mean patch size

Median patch size

Patch size standard deviation

Total edge

Mean patch edge

Area weighted mean shape index

Mean perimeter area ratio $|t|$ value $p$ value Significance $^{a}$

$\begin{array}{lll}0.6467 & .5417 & \text { ns } \\ 2.3387 & .0580 & \text { ns } \\ 4.8254 & .0029 & * * \\ 1.9104 & .1047 & \text { ns } \\ 1.3474 & .2265 & \text { ns } \\ 0.0286 & .9781 & \text { ns } \\ 6.2771 & .0008 & * * * \\ 1.5198 & .1794 & \text { ns } \\ 1.9143 & .1041 & \text { ns }\end{array}$

Note: The tests were paired across the seven watersheds with patches in all four layers.

a $* * *=p<.001 ; * *=p<.01 ; \mathrm{ns}=$ not significantly different. 


\section{DISCUSSION}

\section{Remote Sensing of Forest Pattern and Disturbance Processes}

Satellite images provide a discrete snapshot in time, while landscape disturbance processes are continuous. Multitemporal images (e.g., both pre- and postdisturbance) are generally preferred given an ability to capture disturbance processes because delta images provide a viewable measure of land cover change rather than a snapshot of land cover condition (White et al., 1996). However, care must be taken in image selection for multitemporal analysis for two reasons. First, the image sensors should be compatible. The Landsat data record is most useful given its current length of more than 34 years, which is commensurate with the temporal scale of many forest disturbance processes.

The second reason lies not with the sensor but with the scene. Other vectors of change are captured in delta images besides the disturbance processes of interest. Topographic shadows dramatically affect spatial patterns in rugged terrain such as in our study area, making it highly desirable to choose pre- and postdisturbance images with similar solar illumination conditions. We chose a 9 September 2001 prefire image because it much more closely matched the acquisition months of our two postfire images than the 10 July 2002 image, even though the latter was acquired more recently before the fire. For the same reason, we chose to subtract the 10 July 2002 image from the 31 July 1995 image to indicate prefire stand-replacing disturbance. The months from July to September are typically dry in the northern Rocky Mountains, which greatly influences vegetation phenology. Southern aspects are relatively drier, with sparser tree cover, making the background reflectance more influential and seasonally dynamic. Provided such caveats can be met, delta images are more informative than single-date images for characterizing disturbance.

The 2001-2004 dNBR (Figure 8.4B) and 2001-2004 dNDVIc (Figure 8.5) polygon layers exhibit a highly similar pattern. This is to be expected given that both indices originated from the same source images, and NBR and NDVIc are highly correlated because they share the same near-infrared band. We chose NDVIc over NDVI to indicate forest biomass based not only on literature support (Nemani et al., 1993; Pocewicz et al., 2004) but also because NDVIc has less in common with NBR than NDVI (compare Equation 8.1 and Equation 8.2). While BAER teams prefer NBR over NDVI for the greater sensitivity of NBR to soil effects (Parsons, 2003), both indices are highly sensitive to vegetation cover (Hudak, Morgan, et al, 2004; Hudak, Robichaud, et al., 2004). At the Cooney Ridge wildfire, NBR and dNBR-based BARC maps used by BAER teams showed the largest proportion of high burn severity along the ridge forming the eastern boundary of Watersheds 10 and 11, which our NBR and dNBR layers corroborate (Figure 8.4B).

\section{Patch Characteristics of Stand-Replacing Harvest and Fire Disturbance}

We chose a consistent and objective threshold of two standard deviations from the mean to define stand-replacing disturbance, whether induced by harvest or fire. We felt that the absence of spatially explicit field data to indicate subtler timber harvest practices

(e.g., thinning) defining stand-I and fire disturb the ground. Ho bance patches $\mathrm{i}$ effects both imn to the extent of $]$ 8.1), which act Like virtua heterogeneous, wildfire perime recommend our the mean for ac which becomes mapping the ex cuts will be om we considered closely matchin would include $n$ thematic classif.

Results fron on average, had than stand-repla results in forest . lengths, greater habitat (Reed et such as fire, inst

Stand-replac and fire disturbar of landscape pat activity, fire was topography and forest pattern, $y_{t}$ roads are now tr public lands, par many roads to fa et al., Chapter 1 logging and recr ation in forests historically the $\mathrm{F}$ and closer to the

\section{INTERACTION OF}

Our intent was to harvest or fire dis 
(e.g., thinning) or less-severe burns justified choosing a conservative threshold for defining stand-replacing disturbance. The location of the major stand-replacing harvest and fire disturbance patches, as indicated in Figure 8.5, matched our observations on the ground. However, we believe that the extent of the mapped stand-replacing disturbance patches is conservative (Figure 8.5) based on our field observations of postfire effects both immediately and one year after the fire; they are very conservative compared to the extent of harvest and fire disturbances suggested by the geographic layers (Figure 8.1), which actually much more closely resemble our impressions on the ground.

Like virtually all large wildfires, the Cooney Ridge postfire landscape was very heterogeneous, with patches varying in size and shape. Many patches within the wildfire perimeter were lightly burned, and some remained unburned. We do not recommend our image analysis approach of classifying pronounced departures from the mean for accurate mapping of burn area extent (see Hudak and Brockett, 2004), which becomes difficult at low severities. Similarly, this approach is not ideal for mapping the extent of timber harvest areas (see Cohen et al., 1998) as many partial cuts will be omitted. Encouragingly, the 1995 and 2002 NDVIc polygon layers that we considered indicative of stand-replacing harvest (Figure 8.4A) show a pattern closely matching (but with more limited extent) that of nonforested lands (which would include more partial cutting) mapped by the RSAC image analyst using See 5 thematic classification software (Figure 8.5).

Results from this case study demonstrated that stand-replacing harvest patches, on average, had significantly less area (mean patch size) and edge (mean patch edge) than stand-replacing fire patches (Table 8.4 and Table 8.5). In general, clearcutting results in forest pattern characterized by smaller patch sizes, smaller patch perimeter lengths, greater distances between patches, more edge habitat, and less interior habitat (Reed et al., 1996) when compared to patterns created by natural processes such as fire, insect outbreak, avalanches, and blowdowns (Tinker and Baker, 2000).

Stand-replacing harvest (Cohen et al., 1998; Healey et al., Chapter 3, this volume) and fire disturbances (Hessburg et al., 2000) may be the principal current determinants of landscape pattern. Prior to European settlement and significant timber-harvesting activity, fire was the principal disturbance shaping landscape pattern. Undoubtedly, topography and other disturbances such as insects, disease, and wind also influenced forest pattern, yet fire effects are coupled to all of these. Timber harvest, fire, and roads are now the principal determinants of landscape pattern on many private and public lands, particularly in mid- to high-elevation mixed-conifer forests that have many roads to facilitate fire detection and suppression (Hessburg et al., 2000; Linke et al., Chapter 1, this volume), which are high priorities in landscapes subject to logging and recreational use. Moreover, the primary spatial scale of structural variation in forests today is at the stand level due to harvesting "footprints," while historically the primary scale of forest structural variation may have been broader and closer to the scale at which burn patches vary across the landscape.

\section{Interaction of Forest Harvest and Fire Disturbance Processes}

Our intent was to consistently and objectively define patches resulting from forest harvest or fire disturbances. While consistency and objectivity are always advisable, 
they are especially important when presenting results without the benefit of geolocated validation data for accuracy assessment. However, we have been heavily involved with wildfire research at Cooney Ridge, where we have measured prefire fuels and active fire characteristics at one site and made extensive postfire effects measurements at this and several other sites distributed across the entire landscape (Morgan et al., 2004). These field data were gathered prior to this analysis and to meet different objectives, but in the process of crisscrossing the area while conducting fieldwork, we became very familiar with the entire Cooney Ridge postfire landscape. The significantly higher association (Figure 8.3, Table 8.3) of private lands with largely harvested lands, compared to public lands, was confirmed by our observations on the ground, the patterns visually apparent in the satellite imagery (Figure 8.2), and the consistent and objective density slicing approach we used to delineate stand-replacing disturbance events (Figure 8.4 and Figure 8.5).

The most unexpected result from the patch metrics analysis is the similarity between the 1995-2002 dNDVIc and 2001-2004 dNDVIc patch metrics. No significant differences were found across all nine metrics. The 1995-2002 dNDVIc map shows that the areas of greatest vegetation change within the study area in this time interval occurred in Watersheds 7, 10, and 11. The large polygons in Watershed 7 can be attributed to the 700-Ha 1998 Gilbert Creek 2 fire (Gilbert Creek Fire Incident Action Plan, 1998), part of which reburned through the 226-Ha 1985 Gilbert Creek 1 fire. Both fires occurred in early September (Ed Mathews, U.S. Forest Service Missoula Fire Sciences Lab, email, 1 December 2005). The large polygons in Watersheds 10 and 11 can be attributed to large clearcuts on the private industrial forest land that comprises most of these watersheds (Figure 8.5). Enough time elapsed since these disturbances to allow shrubs and herbaceous vegetation to recover, thus increasing the 10 July 2002 NDVIc values sufficiently to escape detection in the single-date density slice of this image (Rogan et al., 2002). This exemplifies the value of delta images over single-date images for disturbance mapping, especially as time elapses until the acquisition of the postdisturbance image (Hudak and Brockett, 2004).

Timing of image acquisitions heavily influenced our results and interpretation. The clearcut areas in Watersheds 10 and 11 were mapped as severely burned using NBR derived from immediate postfire imagery that RSAC used to produce a BARC map (Stone et al., 2004). Many of these same clearcuts were no longer mapped as severely burned when NBR and dNBR were derived from postfire imagery acquired one year later (Figure 8.4B and Figure 8.5). This exemplifies the merit of one-year postfire images for extended assessments of burn severity because the degree of postfire vegetation regrowth is in itself a very useful indicator of ecological impact (Key and Benson, in press).

Most of the areas mapped as severely burned in our analysis were on steep, upper slopes adjacent to and above clearcuts. The 1995-2002 dNDVIc and 2001-2004 dNDVIc polygons clearly do not overlap (Figure 8.5) because following a clearcut there is little biomass remaining to burn compared to a mature forest: However, what is more remarkable is the obvious adjacency of the polygons in these two independently derived layers. The adjacency of the 1995-2002 dNDVIc polygons on the eastern side of Watersheds 10 and 11 to the 2001-2004 dNDVIc 
polygons immediately east (i.e., on either side of the ownership boundary) matches our field observations. Strong westerly winds on 16 and 17 August 2003 caused extreme fire behavior and the fastest fire progression of all days on the Cooney Ridge wildfire based on unpublished GIS data obtained from fire managers (Stone et al., 2004). We believe that availability of abundant dry fuel stemming from recent clearcuts on the private lands in Watersheds 10 and 11 coupled with extremely low fuel moistures, local topography, and very hot, dry, windy weather all contributed to the rapid advance of intensely burning fire from the clearcut private lands into the standing timber on public land. This resulted in the large, severely burned patches along the ridge defining the eastern edge of Watersheds 10 and 11 (Figure 8.5). In many mid- to high-elevation forests common in the northern Rocky Mountains, weather and topography rather than fuels are often the primary variables determining fire size and severity (Bessie and Johnson, 1995; Sherriff et al., 2001; Turner et al., 1994).

Together, the large clearcuts on private lands and the extensively burned areas on both private and public lands created large, relatively homogeneous patches with few trees. Although shrubs and grasses will rapidly regrow, the lack of tree cover, especially on steep slopes, could contribute to soil erosion. Postlogging tree planting and postburn rehabilitation are designed to hasten tree establishment and to mitigate possible soil erosion. To the credit of local managers, we did observe many newly planted tree seedlings in Watershed 11 one year after the wildfire.

\section{CONCLUSIONS}

This case study illustrates the importance of landscape context in determining severe burn patterns. Fuels, weather, and topography interact to determine active fire behavior and subsequent postfire effects (Pyne et al., 1996). Unfortunately, current understanding of these interactions is limited. Land use features such as roads and clearcuts can fragment forested landscapes (Bresee et al., 2004). Fire management decisions also alter landscape pattern. Fire managers are very successful at suppressing the vast majority of fires, so most are small. Hessburg et al. (2000) quantified a high degree of change and variability in forest landscape pattern over 60 years across Idaho, Montana, and Washington and attributed this to the combined effects of fire exclusion and other land uses. In further analysis of their data, Black et al. (2003) found that changes in forest patterns across mountainous landscapes were correlated with both human and biophysical factors.

Fire and other disturbances have played important ecological roles in western coniferous forest ecosystems. In extreme years, especially after prolonged drought, extensive areas burn across the western United States (Swetnam and Betancourt, 1990, 1998). Such years account for the majority of the area burned (Strauss et al., 1989) and the greatest threats to people and property (Maciliwain, 1994). Fuel management through logging or other means will be less effective when drought and weather conditions are extreme, as they were in western Montana in 2003. One of the clearest lessons from history is that fires have always occurred, and they will continue to occur despite our efforts to detect and suppress them (Morgan et al., 2003). In most forest ecosystems in western North America, biomass production 
Stand-Replacing

exceeds decomposition; this accumulated biomass fuels fires when lightning or people ignite fires in hot, dry, windy conditions. An understanding of where fires are more likely to be severe would help to strategically locate and design fuel management treatments where they will be most effective. Such an understanding would also be helpful in strategic fire suppression, fire mitigation, and postfire rehabilitation decisions.

Like all real landscapes, the Cooney Ridge landscape is unique. Thus, it would be misguided to generalize our case study results and interpretation to other landscapes, which have their own unique contexts. Yet, the disturbance processes observed at Cooney Ridge are common to other forested landscapes shaped by timber harvest and fire, as nearly all forested landscapes are to some degree. The recent, dramatic disturbance history at Cooney Ridge creates a fertile setting for exploring how human and natural disturbances interact to shape landscape pattern. This case study may raise more questions than it answers; in fact, we hope that it does. We encourage others to think about how they might also use remote sensing and GIS tools for quantifying landscape patterns, which can provide a window for better understanding of landscape disturbance processes.

\section{ACKNOWLEDGMENTS}

This research was supported in part by funds provided by the Rocky Mountain Research Station, Forest Service, U.S. Department of Agriculture, in cooperation with the University of Idaho (JVA 03-JV-11222065-279), through funding from the USDA/USDI Joint Fire Science Program, Project 03-2-1-02, entitled, "Assessing the Causes, Consequences and Spatial Variability of Burn Severity: A Rapid Response Project." We thank Jeffrey Evans at the RMRS Moscow Forestry Sciences Laboratory for delineating the watershed boundaries; Bonnie Ruefenacht at RSAC for producing the See 5 forest/nonforest classification; Ed Mathews and Colin Hardy at the RMRS Missoula Fire Sciences Laboratory for identifying the Gilbert Creek fires; Rudy King for statistical advice; and Mike Wulder, Dennis Ferguson, Henry Shovic, and three anonymous reviewers for their helpful comments.

\section{REFERENCES}

Bessie, W.C. and Johnson, E.A. (1995). The relative importance of fuels and weather on fire behavior in subalpine forests. Ecology, 76, 747-762.

Black, A.E., Morgan, P., and Hessburg, P.F. (2003). Social and biophysical correlates of change in the landscape structure of forests in the interior Columbia River Basin. Ecological Applications, 13, 57-67.

Bresee, M.K., Le Moine, J., Mather, S., Brosofske, K.D., Chen, J., Crow, T.R., and Rademacher, J. (2004). Disturbance and landscape dynamics in the Chequamegon National Forest, Wisconsin, USA, from 1972 to 2001. Landscape Ecology, 19, 291-309.

Brockett, B.H., Biggs, H.C., and van Wilgen, B.W. (2001). A patch mosaic burning system for conservation areas in southern African savannas. International Journal of Wildland Fire, 10, 169-183. 
Chander, G. and Markham, B. (2003). Revised Landsat-5 TM radiometric calibration procedures and postcalibration dynamic ranges. IEEE Transactions on Geoscience and Remote Sensing, 41, 2674-2677.

Cohen, W.B., Fiorella, M., Gray, J., Helmer, E., and Anderson, K. (1998). An efficient and accurate method for mapping forest clearcuts in the Pacific Northwest using Landsat imagery. Photogrammetric Engineering and Remote Sensing, 64, 293-300.

Cooney Ridge Complex Fire Narrative. (2003). MT-SWS-000149. USDA Forest Service Region 6. 22p.

De Bano, L.F., Neary, D.G., and Ffolliott, P.F. (1998). Fire's Effects on Ecosystems. John Wiley and Sons, New York. 333p.

Elkie, P., Rempel, R. and Carr, A. (1999). Patch Analyst User's Manual. Ontario Ministry of Natural Resources. Northwest Science and Technology, Thunder Bay, ON, Canada. TM-002. 16pp plus Appendix.

Fischer, W.C. and Bradley, A.F. (1987). Fire Ecology of Western Montana Forest Habitat Types. USDA Intermountain Research Station, Ogden, UT. General Technical Report INT-223. 95p.

Gilbert Creek Fire Incident Action Plan. (4 September 1998). Lolo National Forest, MT. 19p. Graham, R.T. (Tech. Ed.). (2003). Hayman Fire Case Study. USDA Forest Service, Ogden, UT. GTR-RMRS-114. 396p.

Gustafson, E.J. (1998). Quantifying landscape spatial pattern: what is the state of the art? Ecosystems, 1, 143-156.

Hessburg, P.F., Smith, B.G., Salter, R.B., Ottmar, R.D., and Alvarado, E. (2000). Recent changes (1930s-1990s) in spatial patterns of interior northwest forests, USA. Forest Ecology and Management, 136, 53-83.

Hudak, A.T. and Brockett, B.H. (2004). Mapping fire scars in a southern African savannah using Landsat imagery. International Journal of Remote Sensing, 25, 3231-3243.

Hudak, A.T., Fairbanks, D.H.K., and Brockett, B.H. (2004). Trends in fire patterns in a southern African savanna under alternative land use practices. Agriculture, Ecosystems and Environment, 101, 307-325.

Hudak, A., Morgan, P., Stone, C., Robichaud, P., Jain, T., and Clark, J. (2004). The relationship of field burn severity measures to satellite-derived burned area reflectance classification (BARC) maps. American Society for Photogrammetry and Remote Sensing Annual Conference Proceedings (pp. 96-104). CD-ROM. ASPRS, Bethesda, MD.

Hudak, A., Robichaud, P, Evans, J., Clark, J., Lannom, K., Morgan, P., and Stone, C. (2004). Field validation of burned area reflectance classification (BARC) products for post fire assessment. Proceedings of the Tenth Biennial Forest Service Remote Sensing Applications Conference. CD-ROM. 13p.

Johnson, E.A., Morin, H., Miyanishi, K., Gagnon, R., and Greene, D.F. (2003). A process approach to understanding disturbance and forest dynamics for sustainable forestry. In P.J. Burton, C. Messier, D.W. Smith, and W.L. Adamowicz (Eds.), Towards Sustainable Management of the Boreal Forest. (pp. 261-306). National Research Council Research Press, Ottawa, ON, Canada. 1039p.

Key, C.H. and Benson, N.C. (In press). Landscape assessment: ground measure of severity, the composite burn index; and remote sensing of severity, the normalized burn ratio. In D.C. Lutes, R.E. Keane, J.F. Caratti, C.H. Key, N.C. Benson, and L.J. Gangi (Eds.), FIREMON: Fire Effects Monitoring and Inventory System. USDA Forest Service, Rocky Mountain Research Station, Fort Collins. General Technical Report.

Kimmins, J.P. (1997). Forest Ecology: A Foundation For Sustainable Management. (2nd ed.). Prentice-Hall, Englewood Cliffs, NJ. 596p. 
Lewis, S.A., Wu, J.Q., and Robichaud, P.R. (2006). Assessing burn severity and comparing soil water repellency, Hayman Fire, Colorado. Hydrological Processes, 20, 1-16.

Maciliwain, C. (1994). Western inferno provokes a lot of finger-pointing but not much action. Science, 370, 585.

Mladenoff, D.J., White, M.A., Pastor, J., and Crow, T.R. (1993). Comparing spatial pattern in unaltered old-growth and disturbed forest landscapes. Ecological Applications, 3 , 294-306.

Moore, M.M., Covington, W.W., and Fule, P.Z. (1999). Reference conditions and ecological restoration: a southwestern ponderosa pine perspective. Ecological Applications, 9, $1266-1277$.

Moreno, J.M. and Oechel, W.C. (1989). A simple method for estimating fire intensity after a burn in California chaparral. Ecologica Plantarum, 10, 57-68.

Morgan, P., Defosse, G.E., and Rodriguez, N.F. (2003). Management implications of fire and climate changes in the western Americas. In T.T. Veblen, W.L. Baker, G. Montenegro, and T.W. Swetnam (Eds.), Fire and Climatic Change in Temperate Ecosystems of the Western Americas (pp. 413-440). Springer-Verlag, New York. Ecological Studies 160.

Morgan, P., Hudak, A., Robichaud, P., and Ryan, K. (2004). Assessing the Causes, Consequences and Spatial Variability of Burn Severity: A Rapid Response Proposal. Retrieved from http://www.cnrhome.uidaho.edu/burnseverity. JFSP project 03-21-02. Progress Report. September 2004.

NASA. (1989). Landsat-7 Science Data User's Handbook. NASA/Goddard Space Flight Center, Greenbelt, MD.

Nemani, R.R., Pierce, L., Running, S., and Band, L. (1993). Forest ecosystem processes at the watershed scale: sensitivity to remotely-sensed leaf area index estimates. International Journal of Remote Sensing, 14, 2519-2534.

Parsons, A. (2003). Burned Area Emergency Rehabilitation (BAER) Soil Burn Severity Definitions and Mapping Guidelines. Burn Severity Definitions/Guidelines Draft. 12p. USDA Forest Service, Remote Sensing Applications Center. Salt Lake City, UT. (Unpublished report.)

Pocewicz, A.L., Gessler, P., and Robinson, A. (2004). The relationship between effective plant area index and Landsat spectral response across elevation, solar insolation, and spatial scales in a northern Idaho forest. Canadian Journal of Forest Research, 34, 465-480.

Pritchett, W.L. and Fisher, R.F. (1987). Properties and Management of Forest Soils. 2nd ed. John Wiley and Sons, New York. 494p.

Pyne, S.J., Andrews, P.L., and Laven, R.D. (1996). Introduction to Wildland Fire. 2nd ed. John Wiley and Sons, New York. 769p.

R Development Core Team. (2004). R: A Language and Environment for Statistical Computing. $\mathrm{R}$ Foundation for Statistical Computing, Vienna, Austria. Retrieved from http://www.R-project.org. October 24, 2004.

Reed, R.A., Johnson-Barnard, J., and Baker, W.L. (1996). Contribution of roads to forest fragmentation in the Rocky Mountains. Conservation Biology, 10, 1098-1106.

Riitters, K.H., O’Neill, R.V., Hunsaker, C.T., Wickham, J.D., Yankee, D.H., Timmins, S.P., Jones, K.B., and Jackson, B.L. (1995). A factor analysis of landscape pattern and structure metrics. Landscape Ecology, 10, 23-39.

Rogan, J., Franklin, J., and Roberts, D.A. (2002). A comparison of methods for monitoring multitemporal vegetation change using Thematic Mapper imagery. Remote Sensing of Environment, 80, 143-156.

Rowe, J.S. (1983). Concepts of fire effects on plant individuals and species. In R.W. DeBano and D.A. MacLeans (Eds.), The Role of Fire in Northern Circumpolar Ecosystems (pp. 135-154). John Wiley and Sons, New York. 322p. 
Ryan, K.C. (2002). Dynamic interactions between forest structure and fire behavior in boreal ecosystems. Silva Fennica, 36, 13-39.

Ryan, K.C. and Noste, N.V. (1985). Evaluating prescribed fires. In J.E. Lotan, B.M. Kilgore, W.C. Fisher, and R.W. Mutch (coordinators), Proceedings, Symposium and Workshop on Wilderness Fire (pp. 230-238). November 15-18, 1983, Missoula, MT. USDA Forest Service, General Technical Report INT-182.

Savage, M. and Nystrom Mast, J. (2005). How resilient are southwestern ponderosa pine forests after crown fires? Canadian Journal of Forest Research, 35, 967-977.

Schimmel, J. and Granstrom, A. (1996). Fire severity and vegetation response in the boreal Swedish forest. Ecology, 77, 1436-1450.

Sherriff, R.L., Veblen, T.T., and Sibold, J.S. (2001). Fire history in high elevation subalpine forests in the Colorado Front Range. Ecoscience, 8, 369-380.

Smith, D.M., Larson, B.C., Kelty, M.J., and Ashton, P.M.S. (1996). The Practice of Silviculture: Applied Forest Ecology. 9th ed. John Wiley and Sons, New York. 537p.

Stone, C., Hudak, A., and Morgan, P. (2004). Forest harvest can increase subsequent forest fire severity. International Symposium on Fire Economics, Policy and Planning: A Global Vision (pp. 154-163). CD-ROM. University of Córdoba, Córdoba, Spain. Editor: Armando González-Cabán.

Strauss, D., Bednar, L., and Mees, R. (1989). Do one percent of the forest fires cause 99\% of the damage? Forest Science, 35, 319-328.

Swetnam, T.W. and Betancourt, J.L. (1990). Fire-southern oscillation relations in the southwestern United States. Science, 249, 1017-1020.

Swetnam, T.W. and Betancourt, J.L. (1998). Mesoscale disturbance and ecological response to decadal-scale climate variability in the American Southwest. Journal of Climate, $11,3128-3147$.

Tinker, D.B. and Baker, W.L. (2000). Using the LANDLOG model to analyze the fragmentation of a Wyoming forest by a century of clear-cutting. In R.L. Knight, F. W. Smith, S.W. Buskirk, W.H. Romme, and W.L. Baker (Eds.), Forest Fragmentation in the Southern Rocky Mountains (pp. 337-358). University Press of Colorado, Boulder, Colorado, USA.

Turner, M.G., Hargrove, W.W., Gardner, R.H., and Romme, W.H. (1994). Effects of fire on landscape heterogeneity in Yellowstone National Park, Wyoming. Journal of Vegetation Science, 5, 731-742.

Turner, M.G., Romme, W.H., Gardner, R.H., and Hargrove, W.W. (1997). Effects of fire size and pattern on early succession in Yellowstone National Park. Ecological Monographs, 67, 411-433.

White, J.D., Ryan, K.C., Key, C.C., and Running, S.W. (1996). Remote sensing of forest fire severity and vegetation recovery. International Journal of Wildland Fire, 6, 125-136. 